\title{
Influence of effective microorganisms on soil biogenicity parameters in the rhizosphere of different soybean genotypes and soybean yield
} \author{
Marija Cvijanović ${ }^{4}$ Asija Mussa Abduladin' \\ ${ }^{1}$ University Megatrend, Faculty of Biofarming Bačka Topola, Serbia \\ ${ }^{2}$ University of Kragujevac, Institute for Information Technologies, Kragujevac, Serbia \\ ${ }^{3}$ Institute of Field and Vegetable Crops, Novi Sad, Serbia \\ ${ }^{4}$ University of Bijeljina, Faculty of Agriculture, Bijeljina, BiH
}

Eltreki Abduladin ${ }^{1}$ - Gorica Cvijanović ${ }^{2 *}$ - Vojin Đukić ${ }^{3}$. Nenad Đurić ${ }^{1}$ - Zlatica Miladinov ${ }^{3}$.

\begin{abstract}
Summary: The aim of the study was to determine the effects of applying effective microorganisms (EM) on the basic microbiological parameters of soil and soybean yield biological value. The research was conducted in the period 2016 2018. Factor A are the years 2016-2018, factor B are soybean genotypes Galina, Sava, Rubin, and factor C application of EM: variant 1 was control, variant 2 was EM in soil $20 \mathrm{lha}^{-1}$ and foliar treatment in the stage of plant development from three to four trefoils and budding stage, $5 \mathrm{lha}^{-1}$, variant 3 was NPK fertilizer (8:15:15), $300 \mathrm{kgha}^{-1}$, and variant 4 was a combination of variant 2 and variant 3 . During full flowering, the basic parameters of soil biogenicity were determined by the total number of microorganisms (TNB) and the number of azotobacter (AZT) and grain yield at the end of the growing period. The examined factors had a statistically significant influence on the examined parameters. Soil biogenicity parameters in variant $4 \mathrm{EM}+\mathrm{NPK}$ were statistically significantly $(\mathrm{p}<0.01)$ higher than control and variant 3. Variant 2 affected a higher number of $\mathrm{p}<0.01$ compared to control, while compared to other variants significance was $\mathrm{p}<0.05$ (factor $\mathrm{B}$ ). The highest number of all examined parameters was in the rhizosphere of Rubin genotype (factor C). Variant 2 with EM increased in yield of $13.29 \%$ compared to the control which was at the level $(p<0.05)$ and with the application of EM + NPK variant 4 the yield was higher by $15.95 \%$ which was at the level $(\mathrm{p}<0.01)$ of significance.

Key words: effective microorganisms, soybean, soil biogenicity, yield
\end{abstract}

\section{Introduction}

The development of sustainable agriculture intensifies research into the application of different groups of microorganisms that have a role in preventive protection and supplementary plant nutrition. In modern research, preparations with different groups of microorganisms are increasingly used, which provide good conditions for achieving stable yields while preserving the quality of the soil. The application of effective microorganisms (EM) is today the subject of

\section{Corresponding author}

cvijagor@yahoo.com

Acknowledgements:

This research was supported by the Ministry of Education, Science and Technological Development of the Republic of Serbia, grant number: 451-03$68 / 2020-14 / 200378$ and $451-03-68 / 2020-14 / 200032$

Cite this article:

Abduladin E, Crijanović G., Dukić V., Đurić N., Miladinov Z., Criianović M, Mussa Abduladin A. (2020). Evaluation of respiratory activity of albic luvisol contaminated by zinc and nickel during spring rapeseed cultivation. Ratar. Port, 57 (3), $72-79$.

(c) (i) Copyright (c) The Author(s) 2020 many studies in the world (Sabeti et al., 2017; Higa, 2001). Effective microorganisms (EM) are a good combination of free aerobic and anaerobic microscopic organisms, which are found in nature. The main types of microorganisms that are present in preparations with EM are lactic acid bacteria (Lactobacillus plantarum, Lactobacillus casei, Streptococcus lactis) photosynthetic bacteria (Rhodopseudomonas palustris and Rhodobacter spharoides), yeasts, actinomycetes and various species of fungi. These types of microorganisms produce large amounts of aminoacids, enzymes, hormones, antibiotics, vitamins and other bioactive compounds, which are directly absorbed by plants (Kim \& Lee, 2000; Ranjithisar, 2007), and can be substrates for bacteria and to increase the diversity of microflora in the soil. When introduced into the soil, they accelerate the decomposition of cellulose, lignin, and substances that control the development of phytopathogenic organisms (Higa, 2000). The use of effective microorganisms (EM) can reduce the amounts of chemical fertilizers, increase the yield parameters of plants, as well as the amount of biologically active substances in fruits and seeds. 
According to Sabeti et al. (2017), the application of EM in the soil reduced the negative effect of salinity on the morphology of corn roots. They also found that the application of EM to the soil and foliar treatment of sweet corn can increase the dry weight of the roots, root volume and length of the shoot. The use of free diazotrophs in soybean production can achieve stable yields and maintain soil biogenicity (Cvijanović et al., 2007), as well as reduce the negative impact of drought (Cvijanović and Dozet, 2018).

According to Javid (2006), foliar application of EM with the use of NPK fertilizers in the production of peas (Pisum sativum L.) increases the number of nodules at the root of peas by $217 \%$ and the biomass of nodules by $167 \%$. Also, it was found that fertilization with effective microorganisms and NPK fertilizers increased grain yield by $126 \%$, and in combination with organic fertilizer the increase in grain yield was $145 \%$. The same author has found that by applying the EM in wheat production can increase yield by $27 \%$ compared with the production of which are applied only chemical fertilizers. In the production of maize with the use of organic fertilizers and preparations with effective microorganisms, it is possible to increase the yield parameters and yield of maize grains (Priyadi et al., 2005). Similarly, Xiaohou et al. (2001) stated that spraying with effective microorganisms can increase the yield and quality of different crops. By adding photosynthetic bacteria to the soil, the content of other effective microorganisms increases, e.g. mycorrhizal fungi. The increase in mycorrhizal fungi in the rhizosphere is due to more available nitrogen compounds (amino acids) which are the secretions of photosynthetic bacteria. These fungi can coexist with nitrogen-fixing bacteria, increasing nitrogen-fixing ability and grain yield.

Soybean is a plant species that has an extremely great economic and agro-technical significance, so it has been the focus of many researches in recent decades. Soybean has more importance for the production of biogas in a circular economy (Milanović et al., 2020). The use of symbiotic bacteria of the Rhizobium family in the cultivation of soybeans has become a mandatory measure. Bacterial species such as Bradyrbiqobium japonicum, Bradyrbizobium elkani and Sinorhizobium fredii are able to provide up to $70 \%$ of the nitrogen needed for optimal soybean production in the process of biological nitrogen fixation (Martinez-Romero and CaballeroMellado, 1996). The remaining $30 \%$ of the nitrogen must be provided in a way which must respect the principles of good agricultural practice and preserve soil quality. One of the basic conditions for good soil quality is to increase the diversity of the soil microbial population. Increasing the total number of microorganisms as well as individual physiological groups creates good conditions for achieving high and quality yields.
The main objective of this study was to determine the impact of EM application on soil biogenicity parameters in the soybean rhizosphere and grain yield in three-year studies.

\section{Material and Methods}

The research was conducted in the period 20162018 on chernozem type land. The experiment was set up according to the design of a split-plot on an area of $2475 \mathrm{~m}^{2}$ in the experimental field Rimski Sancevi at the Institute of Field and Vegetable Crops in Novi Sad. The size of the basic plot was $15 \mathrm{~m}^{2}$ (six rows of soybeans with a row spacing of $50 \mathrm{~cm}$ and a row length of $5 \mathrm{~m}$ ). Four central rows were used to analyze the examined parameters. In the experiment, three factors were set in four repetitions. All agrotechnical measures were implemented in optimal deadlines and correctly.

Factor A: years 2016-2018 (2016 with the most optimal weather conditions for soybean production, 2017, with a pronounced dry period and very high temperatures, unfavorable for soybean production and 2018, favorable for soybean production).

Factor B: genotypes of different soybean ripening groups selected by the Institute of Field and Vegetable Crops Novi Sad (1. Galina, 0 ripening group, length of vegetation period of 119 days, 2. Sava, I ripening group, vegetation period length 123 days, 3 . Rubin, II ripening group, length of vegetation period 133 days).

Factor C: fertilization with the following variants:

1. Control, i.e. variant without application of NPK fertilizers and EM Aktiv preparations.

2. Variant with application of effective microorganisms in a liquid preparation under the commercial name EM Aktiv (application on the soil before sowing in the amount of 20 liters per hectare and two foliar treatments in the phase of plant development from three to four trefoils and budding phase, i.e. buds on soybean tree in the amount of $5 \mathrm{lha}^{-1}$ ).

3. Variant with application of NPK fertilizer during basic tillage in autumn, fertilizer formulation $8: 15: 15$, quantity $300 \mathrm{kgha}^{-1}$.

4. Variant with application of NPK fertilizer, formulation $8: 15: 15$, in the amount of $300 \mathrm{kgha}^{-1}$, during basic tillage in autumn and application of effective microorganisms in the form of EM Aktiv $5 \mathrm{lha}^{-1}$ (incorporation into the soil before sowing in the amount of 20 liters per hectare and two foliar treatments during the vegetation - in the development phase of plants from three to four trefoils and in the budding phase, before soybean flowering in the amount of five liters per hectare)

In the phenophase of full flowering - R2 (Fehr and Caviness, 1977 ), $0.5 \mathrm{~cm}$ from the central root and root 
hairs, samples of rhizosphere soil were taken. Samples were taken from the rhizosphere of three plants from the central rows. Microbiological analyzes were performed in the Department of Microbiology, Department of Soybeans at the Institute of Field and Vegetable Crops in Novi Sad. In the samples, the total number of bacteria $\left(\mathrm{TNB} \times 10^{-7}\right)$, azotobacter $(\mathrm{AZB} \times$ $\left.10^{-2}\right)$, were determined by the method of agar plates (Trolldenier, 1996). Appropriate nutrient media were used (Hi Media Laboratories Pvt. Limited, Mumbai, India): nutrient agar for the total number of bacteria, synthetic agar for the number of actinomycetes, and azotobacter medium with mannitol for the number of azotobacter. At the end of the vegetation, the grain yield was measured and calculated at $14 \%$ moisture.

\section{Agrometeorological conditions for the period 2016-2018}

Soybean requires larger amounts of moisture in the first phases of development, and in the later stages from flowering to maturation, a good distribution of precipitation is necessary. Data on temperatures and precipitation were taken from the website of the Republic Hydrometeorological Institute for the meteorological station Rimski Sančevi (http://www.hidmet.gov.rs/ciril/ meteorologija / klimatologija_godisnjaci.php).

Based on the measurements, it was determined that the average monthly temperatures for the soybean vegetation period in the research years had higher values by $1.1^{\circ} \mathrm{C}$ in $2016,1.6^{\circ} \mathrm{C}$ in 2017 and $2.5^{\circ} \mathrm{C}$ in 2018 in relation to the multi-year average $\left(18.1^{\circ} \mathrm{C}\right)$. Precipitation was higher in 2016 by $+75.6 \mathrm{~lm}^{-2}$ and in $2018+60.9 \mathrm{~lm}^{-2}$ compared to the multi-year average $\left(375.0 \mathrm{~lm}^{-2}\right)$, while in 2017 there was a deficit $-58.5 \mathrm{~lm}^{-2}$ precipitation during the soybean growing season. The highest amount of precipitation per month was in 2016 (the most favorable conditions for soybean production).

At the end of the growing season, the crops were harvested and the yield change was processed to $14 \%$ moisture. The data were statistically processed using STATISTICA 10 software. The significance of the difference between the applied treatments was determined using Fisher's LSD test.

\section{Results}

The dynamics of the total number of microorganisms and individual systematic and physiological groups is a variable value and depends on a number of factors (soil structure, presence of toxicants and anthropogenic impact). The total number of microorganisms gives a picture of the overall condition of the soil and is one of the most important indicators of soil fertility. Azotobacter belongs to the group of the most important associative diazotrophs whose existence has been determined in the microbial niches of the rhizosphere of corn, wheat, sugar beet and sunflower. Due to its sensitivity and certain requirements for the habitat, it reacts violently with its number to all changes. Due to this property, it is a good indicator of all changes in the soil, especially degradation. In our country, free aerobic nitrogen fixers from the genus Azotobacter have been the most researched. In agricultural lands, fertilizers have a high effect on the function and structure of the microbial community (Cinnadurai et al., 2013). Organic fertilizers significantly affect the accumulation of bacteria and increase biomass in the soil (Murugan and Kumar, 2013), while mineral fertilizers significantly affect the reduction of activity and the number of the microbial community (Cvijanović et al., 2007).

Analysis of variance showed that the main sources of variation (age, genotype and fertilization) as well as their interactions had a significant impact on the examined parameters of soil biogenicity. The year as a factor had a statistically significant influence on the examined parameters at the level of $p<0.01$. In 2017, there was statistically the smallest number TNB (97.36 $\left.\times 10^{-7}\right)$ (Table 2) AZB $\left(125.79 \times 10^{-2}\right)$ (Table 3) as well as actinomycetes $\left(22.06 \times 10^{-4}\right)$ (Table 4$)$. If 2016 is taken as the reference year, because it was the most

Table 1. Mean monthly temperatures $\left({ }^{\circ} \mathrm{C}\right)$ and sum of precipitation $\left(\mathrm{m}^{-2}\right)$ for soybean vegetation period 2016-2018

\begin{tabular}{|c|c|c|c|c|c|c|c|c|}
\hline \multirow{2}{*}{ Month } & \multicolumn{3}{|c|}{$\begin{array}{c}\text { Mean monthly } \\
\text { temperatures }\left({ }^{\circ} \mathrm{C}\right)\end{array}$} & \multirow{2}{*}{$\begin{array}{c}\text { Multi-year } \\
\text { average } \\
1964-2015\end{array}$} & \multicolumn{3}{|c|}{$\begin{array}{c}\text { Average monthly } \\
\text { precipitation }\left(\mathrm{lm}^{-2}\right)\end{array}$} & \multirow{2}{*}{$\begin{array}{c}\text { Multi-year } \\
\text { average } \\
1964-2015\end{array}$} \\
\hline & 2016 & 2017 & 2018 & & 2016 & 2017 & 2018 & \\
\hline April & 14.2 & 11.4 & 17.2 & 11.7 & 74.5 & 57.0 & 49.0 & 46.9 \\
\hline May & 16.9 & 17.6 & 20.4 & 17.0 & 85.0 & 82.9 & 64.2 & 67.1 \\
\hline June & 21.7 & 23.2 & 21.5 & 20.0 & 143.2 & 65.7 & 163.2 & 86.5 \\
\hline July & 22.8 & 24.3 & 22.0 & 21.7 & 68.4 & 12.0 & 81.2 & 67.4 \\
\hline August & 21.1 & 24.8 & 24.0 & 21.2 & 45.8 & 17.4 & 51.2 & 59.3 \\
\hline September & 18.5 & 16.9 & 18.5 & 16.9 & 33.7 & 81.5 & 27.1 & 47.8 \\
\hline Average/Sum & 19.2 & 19.7 & 20.6 & 18.1 & 450.6 & 316.5 & 435.9 & 375.0 \\
\hline
\end{tabular}


favorable for soybean production, a significant decrease in the number of microbes was found in 2017 (TNB by $59.64 \%, \mathrm{AZB}$ by $11.5 \%$ ) because it was the largest deficit of precipitation. In 2018, the TNB was determined to be $159.16 \times 10^{-7}$, which was statistically significantly less than in 2016, although the most rain fell in June. The number of AZB was the highest in 2018 (150.76 $\left.\times 10^{-2}\right)$, which was a statistically significantly higher number only compared to $2017\left(142.12 \times 10^{-2}\right)$, while compared to $2016\left(142.12 \times 10^{-2}\right)$ no significant difference was found. This ratio of the number of AZB in 2016 and 2018 is assumed to be the result of approximately the same values of the measured temperature and the amount of precipitation in June, when soil samples were taken.

Factor C significantly influenced the change in abundance in the soybean rhizosphere. There were statistically significant differences between the variants where EM was applied in relation to the control and application of NPK, while there was no statistical significance between the variants with $\mathrm{EM}$. On average for all three years of research, TNB in control was $136.85 \times 10$ ${ }^{-7}$, and with the application of NPK $126.03 \times 10^{-7}$. Both variants had a statistically significantly lower number than in the application of EM in variant $2\left(208.56 \times 10^{-7}\right)$ and in variant $3\left(197.91 \times 10^{-7}\right)$. The number of $A Z B$ applications of EM in variant $2\left(150.84 \times 10^{-2}\right)$, as well as variant 3 with NPK $\left(151.43 \times 10^{-2}\right)$ was statistically significantly higher compared to the control $\left(123.67 \times 10^{2}\right)(\mathrm{p}<0.01)$. Variant $4\left(143.78 \times 10^{-2}\right)$ increased the number of azotobacter to the level of significance of $p<0.05$ compared to the control, while in relation to variants 2 and 3 the number was smaller but not statistically significant.

Similar results were obtained by Dukić et al. (2012) in the study the application of the mixture cultures of Azotobacter chroococcum, A. vinelandi, Derxia sp., Bacillus megatherium, B. licheniformis and B. subtilis increased total number of microorganisms, number of oligonitrophiles, actinomycetes, azotobacter and fungi during the plant growing season.

The use of effective microorganisms (EM) as soil inoculants is based on the principles of natural ecosystems that are maintained, such as: greater diversity and abundance of organisms, greater interaction and a more stable ecosystem. Owing to them, a small contribution is made to the application of these principles in agricultural land and to change the microbiological balance in favor of increased growth, production and plant protection (Higa, 1991). Effective microorganisms are not a substitute for other agrotechnical measures related to plants and soil. Used properly, they can significantly increase the beneficial effects of these measures (Higa and Wididana, 1991) and represent an additional dimension for optimal production.

Table 2. Total number of microorganisms (TNB $\times 10^{-7}$ )

\begin{tabular}{|c|c|c|c|c|c|c|c|}
\hline \multirow{2}{*}{$\begin{array}{l}\text { Year } \\
\text { (A) }\end{array}$} & \multirow{2}{*}{$\begin{array}{l}\text { Genotype } \\
\text { (B) }\end{array}$} & \multicolumn{4}{|c|}{ Fertilizer (C) } & \multirow[b]{2}{*}{$\overline{\mathrm{x}} \mathrm{A} \times \mathrm{B}$} & \multirow[b]{2}{*}{$\overline{\mathbf{x}} \mathrm{A}$} \\
\hline & & 1. Control & 2. EM Activ & 3. NPK & $\begin{array}{l}\text { 4. EMActiv + } \\
\text { NPK }\end{array}$ & & \\
\hline \multirow{4}{*}{2016} & Galina & 208.24 & 297.61 & 186.27 & 275.26 & 241.85 & \multirow{4}{*}{241.26} \\
\hline & Sava & 198.63 & 264.55 & 172.19 & 272.82 & 227.02 & \\
\hline & Rubin & 220.07 & 312.64 & 195.45 & 291.43 & 254.90 & \\
\hline & $\overline{\mathbf{x}} \mathrm{A} \times \mathrm{C}$ & 208.98 & 291.60 & 184.63 & 279.84 & & \\
\hline \multirow{4}{*}{2017} & Galina & 56.25 & 132.47 & 72.73 & 119.46 & 95.23 & \multirow{4}{*}{97.36} \\
\hline & Sava & 68.49 & 129.61 & 65.09 & 120.77 & 95.99 & \\
\hline & Rubin & 62.35 & 138.86 & 80.22 & 126.05 & 100.87 & \\
\hline & $\overline{\mathbf{x}} \mathrm{A} \times \mathrm{C}$ & 62.36 & 133.67 & 72.68 & 122.09 & & \\
\hline \multirow{4}{*}{2018} & Galina & 126.53 & 198.81 & 118.54 & 184.47 & 157.09 & \multirow{4}{*}{159.16} \\
\hline & Sava & 130.67 & 185.49 & 122.22 & 167.11 & 151.37 & \\
\hline & Rubin & 144.28 & 205.17 & 126.40 & 200.59 & 169.11 & \\
\hline & $\overline{\mathrm{x}} \mathrm{A} \times \mathrm{C}$ & 133.83 & 163.16 & 122.39 & 184.06 & $\overline{\mathrm{x}} \mathrm{B}$ & \\
\hline \multirow{4}{*}{$\overline{\mathrm{x}} \mathrm{B} \times \mathrm{C}$} & Galina & 130.34 & 209.63 & 125.84 & 193.06 & 164.71 & \multirow[b]{6}{*}{$\mathrm{A} \times \mathrm{B} \times \mathrm{C}$} \\
\hline & Sava & 132.59 & 197.65 & 119.83 & 186.90 & 159.24 & \\
\hline & Rubin & 142.23 & 218.89 & 134.02 & 206.02 & 175.29 & \\
\hline & $\overline{\mathrm{x}} \mathrm{C}$ & 135.05 & 208.72 & 126.59 & 195.51 & & \\
\hline \multicolumn{6}{|c|}{ Average 2016-2018 } & 166.41 & \\
\hline LSD & A & $\mathrm{B}$ & $\mathrm{C}$ & $\mathrm{A} \times \mathrm{B}$ & $A \times C$ & $\mathrm{~B} \times \mathrm{C}$ & \\
\hline $1 \%$ & 68.73 & 20.64 & 64.37 & 29.62 & 66.50 & 49.62 & 66.12 \\
\hline $5 \%$ & 50.24 & 14.14 & 48.54 & 22.45 & 47.92 & 36.18 & 48.06 \\
\hline
\end{tabular}


Plant-microbial interactions through various mechanisms can positively affect plant growth (Moulin et al., 2001). The effects of plant species are important variables in determining the bacterial composition of the rhizosphere. Plants with their secretions have a significant influence on the interaction with microbes from soil niches. Sugars and acids are present in the secretions, and the number and diversity of the rhizosphere microflora depend on their quantity. Depending on the mass of the roots, the amount of exudate that the plants release into the environment also depends. On average, for all years of research and applied variants, the largest total number was determined in the rhizosphere in the cultivar Rubin (factor B) $\left(175.29 \times 10^{-7}\right)$, which is of the II ripening group and which has the largest green mass. Compared to total number in the rhizosphere of the Sava variety $\left(159.24 \times 10^{-7}\right)$, a statistically significantly higher total number $(p<0.05)$ was found in the Rubin variety, while there was no statistically significant difference compared to the Galina variety. On average for the whole period of study the interaction of $\mathrm{B} \times \mathrm{C}$ was the highest total number of the cultivar Rubin in variant 2: fertilization with $\mathrm{EM}\left(218.89 \times 10^{-7}\right)$, which was also the increase of $53.89 \%$ compared to the control $\left(136.89 \times 10^{-7}\right)$. In variant 4 , the increase was $44.84 \%$.
According to the years of research, the largest increase was determined by the application of $\mathrm{EM}$ in variant 2 $(49.60 \%)$ and variant $4(33.90 \%)$ in 2017 . The obtained results are a significant indicator that the application of EM can reduce the negative impact of agroclimatic conditions. On average, the control variant had the lowest total number of microorganisms.

The influence of the cultivar on the abundance of azotobacter was greatest in the rhizosphere of the cultivar Rubin $\left(181.51 \times 10^{2}\right)$. The determined number on average for all variants in the period 2016-2018 research was statistically significantly higher $(\mathrm{p}<0.01)$ than in the cultivar Galina $\left(111.95 \times 10^{-2}\right)$ and the cultivar Sava $\left(138.86 \times 10^{-2}\right)$.

The number of $A Z$ was highest in the rhizosphere of the Rubin variety using NPK variant $3\left(2012.23 \times 10^{2}\right)$, which is $39.30 \%$ higher than the control $\left(152.35 \times 10^{2}\right)$. EM in variant $2\left(205.91 \times 10^{-2}\right)$, increased the yield of $A Z$ by $35.15 \%$ compared to the control, while variant $4(155.53 \times$ $\left.10^{-2}\right)$ had the lowest percentage increase of $2.08 \%$ compared to control $\left(155.53 \times 10^{2}\right)$.

In the interaction of cultivars and fertilization by years of research, it was determined that the cultivar Rubin in 2016 had the highest number in variant 3 $\left(156.82 \times 10^{-2}\right)$, in 2017 in variant $2\left(234.51 \times 10^{-2}\right)$. In 2018 , the largest number of $\mathrm{AZ}$ was in the rhizosphere of the Rubin variety in variant $2\left(253.66 \times 10^{-2}\right)$.

Table 3. The number of $A Z$ in soybean thizosphere $\left(A Z B \times 10^{-2}\right)$

\begin{tabular}{|c|c|c|c|c|c|c|c|}
\hline \multirow[b]{2}{*}{$\begin{array}{l}\text { Year } \\
\text { (A) }\end{array}$} & \multirow[b]{2}{*}{$\begin{array}{l}\text { Genotype } \\
\text { (B) }\end{array}$} & \multicolumn{4}{|c|}{ Fertilizer (C) } & \multirow[b]{2}{*}{$\overline{\mathrm{x}} \mathrm{A} \times \mathrm{B}$} & \multirow[b]{2}{*}{$\overline{\mathrm{X}} \mathrm{A}$} \\
\hline & & 1. Control & 2. EM Activ & 3. NPK & $\begin{array}{l}\text { 4. EM Activ } \\
\text { NPK }\end{array}$ & & \\
\hline \multirow{4}{*}{2016} & Galina & 152.43 & 136.92 & 140.65 & 150.88 & 145.22 & \multirow{4}{*}{142.12} \\
\hline & Sava & 86.25 & 145.38 & 97.36 & 201.24 & 132.56 & \\
\hline & Rubin & 161.57 & 129.55 & 232.46 & 154.76 & 169.59 & \\
\hline & $\overline{\mathrm{x}} \mathrm{A} \times \mathrm{C}$ & 133.42 & 137.28 & 156.82 & 168.96 & & \\
\hline \multirow{4}{*}{2017} & Galina & 64.29 & 85.60 & 58.80 & 64.54 & 68.31 & \multirow{4}{*}{125.79} \\
\hline & Sava & 116.24 & 92.49 & 108.28 & 145.81 & 115.71 & \\
\hline & Rubin & 171.28 & 234.51 & 199.28 & 168.33 & 193.35 & \\
\hline & $\overline{\mathbf{x}} \mathrm{A} \times \mathrm{C}$ & 117.27 & 144.06 & 122.12 & 126.23 & & \\
\hline \multirow{4}{*}{2018} & Galina & 136.12 & 127.37 & 128.63 & 97.26 & 122.35 & \multirow{4}{*}{150.76} \\
\hline & Sava & 100.60 & 132.54 & 192.53 & 167.69 & 148.34 & \\
\hline & Rubin & 124.20 & 253.66 & 204.95 & 143.50 & 181.58 & \\
\hline & $\overline{\mathrm{x}} \mathrm{A} \times \mathrm{C}$ & 120.30 & 171.19 & 175.37 & 136.15 & $\bar{x} B$ & \\
\hline \multirow{4}{*}{$\overline{\mathbf{x}} \mathrm{B} \times \mathrm{C}$} & Galina & 117.61 & 116.63 & 109.36 & 104.23 & 111.95 & \multirow[b]{6}{*}{$\mathrm{A} \times \mathrm{B} \times \mathrm{C}$} \\
\hline & Sava & 101.03 & 123.47 & 132.72 & 171.58 & 132.25 & \\
\hline & Rubin & 152.35 & 205.91 & 212.23 & 155.53 & 181.51 & \\
\hline & $\overline{\mathrm{x}} \mathrm{C}$ & 123.67 & 150.84 & 151.43 & 143.78 & & \\
\hline \multicolumn{6}{|c|}{ Average 2016-2018 } & 141,90 & \\
\hline LSD & $\mathrm{A}$ & $\mathrm{B}$ & $\mathrm{C}$ & $\mathrm{A} \times \mathrm{B}$ & $A \times C$ & $\mathrm{~B} \times \mathrm{C}$ & \\
\hline $1 \%$ & 24.8 & 44.86 & 25.17 & 40.29 & 27.44 & 37.61 & 34.82 \\
\hline $5 \%$ & 17.52 & 33.18 & 18.64 & 29.71 & 20.29 & 27.78 & 25.72 \\
\hline
\end{tabular}


Table 4. Influence of EM on grain yield $\left(\mathrm{kg} \mathrm{ha}^{-1}\right)$

\begin{tabular}{|c|c|c|c|c|c|c|c|}
\hline \multirow{2}{*}{$\begin{array}{l}\text { Year } \\
(A)\end{array}$} & \multirow{2}{*}{$\begin{array}{l}\text { Genotype } \\
\text { (B) }\end{array}$} & \multicolumn{4}{|c|}{ Fertilizer (C) } & \multirow[b]{2}{*}{$\overline{\mathrm{x}} \mathrm{A} \times \mathrm{B}$} & \multirow[b]{2}{*}{$\overline{\mathrm{x}} \mathrm{A}$} \\
\hline & & 1. Control & 2. EM Activ & 3. NPK & $\begin{array}{l}\text { 4. EM Activ + } \\
\text { NPK }\end{array}$ & & \\
\hline \multirow{4}{*}{2016} & Galina & 4098.75 & 4461.94 & 4485.95 & 4597.14 & 4410.95 & \multirow{4}{*}{4700.32} \\
\hline & Sava & 4223.51 & 4696.34 & 4658.83 & 4792.95 & 4592.91 & \\
\hline & Rubin & 4651.84 & 5240.94 & 4963.52 & 5332.10 & 5097.10 & \\
\hline & $\overline{\mathrm{X}} \mathrm{A} \times \mathrm{C}$ & 4324.70 & 4799.74 & 4769.43 & 4907.40 & & \\
\hline \multirow{4}{*}{2017} & Galina & 2442.34 & 2911.91 & 2796.86 & 2902.38 & 2763.37 & \multirow{4}{*}{2993.14} \\
\hline & Sava & 2604.15 & 2799.39 & 2941.24 & 3067.14 & 2852.98 & \\
\hline & Rubin & 2724.15 & 3610.89 & 3462.63 & 3654.63 & 3363.07 & \\
\hline & $\overline{\mathrm{X}} \mathrm{A} \times \mathrm{C}$ & 2590.21 & 3107.40 & 3066.91 & 3208.05 & & \\
\hline \multirow{4}{*}{2018} & Galina & 3756.12 & 4185.37 & 4122.59 & 4228.10 & 4073.04 & \multirow{4}{*}{4411.05} \\
\hline & Sava & 4060.04 & 4439.75 & 4433.50 & 4565.09 & 4374.59 & \\
\hline & Rubin & 4352.21 & 4942.55 & 4823.96 & 5023.33 & 4785.51 & \\
\hline & $\overline{\mathrm{X}} \mathrm{A} \times \mathrm{C}$ & 4056.56 & 4522.56 & 4460.02 & 4605.51 & B & \\
\hline \multirow{4}{*}{$\overline{\mathrm{x}} \mathrm{B} \times \mathrm{C}$} & Galina & 3432.40 & 3853.07 & 3801.80 & 3909.21 & 3999.12 & \multirow[b]{6}{*}{$\mathrm{A} \times \mathrm{B} \times \mathrm{C}$} \\
\hline & Sava & 3629.23 & 3978.49 & 4011.19 & 4141.73 & 3940.16 & \\
\hline & Rubin & 3909.40 & 4598.13 & 4416.70 & 4670.02 & 4105.03 & \\
\hline & $\overline{\mathrm{X} C}$ & 3657.01 & 4143.23 & 4076.56 & 4240.32 & & \\
\hline \multicolumn{6}{|c|}{ Average $2016-2018$} & 4118.17 & \\
\hline LSD & A & $\mathrm{B}$ & $\mathrm{C}$ & $\mathrm{A} \times \mathrm{B}$ & $\mathrm{A} \times \mathrm{C}$ & $\mathrm{B} \times \mathrm{C}$ & \\
\hline $1 \%$ & 536.42 & 397.48 & 552.14 & 612.23 & 572.61 & 607.08 & 682.01 \\
\hline $5 \%$ & 380.20 & 288.69 & 398.47 & 446.82 & 408.16 & 440.22 & 524.62 \\
\hline
\end{tabular}

The obtained results are compatible with the results of Sangakkara and Higa (1994) who studied the effect of EM on rhizobacteria (i.e. on nodulation in beans) on soils with low and high population of rhizobacteria. The application of EM significantly increased the number of bacteria in the soil. The biggest changes were in soils with a small population of microorganisms. Nodulation and nitrogenase activity were significantly increased by the application of EM especially in nutrient-poor soils. Javaid (2000) observed a significant increase in mycorrhizal colonization of Vigna radiata due to the application of beneficial microorganisms. In order for populations of beneficial microorganisms to be effective after inoculation, it is important that their initial population in the soil be at a certain critical level. This ensures that the amount of bioactive substances they produce is sufficient to achieve the desired effect in production and/or protection in plants.

The average yield of soybeans in 2016 was $4700.32 \mathrm{kgha}$ -1, and in $20184411.05 \mathrm{kgha}^{-1}$ and these values were statistically very significantly higher compared to 2017 (2993.14 kgha ${ }^{-1}$ ).
Observing the average values for grain yield by individual varieties, it is noticed that the highest value was recorded in the variety of soybean Rubin ( 4105.03 $\left.\mathrm{kgha}^{-1}\right)$, which is statistically very significantly $(\mathrm{p}<0.01)$ higher value compared to the yields in varieties Sava (3940.16 kgha-1) and Galina (3999,12 kgha-1). The average yield by fertilization variants is observed to be the highest value recorded on the variant with EM variant $4\left(4240.32 \mathrm{kgha}^{-1}\right)$, which is statistically very significantly $(p<0.01)$ higher value compared to the control variant of the experiment (3657.01 $\mathrm{kgha}^{-1}$ ) by $15.95 \%$. In variant 2 with the application of EM, the yield was (4143.23 $\mathrm{kgha}^{-1}$ ), which is a significant increase $(p<0.05)$ by $13.29 \%$ compared to the control. The application of NPK (4076.56 kgha-1) did not statistically significantly increase the yield compared to the control. The highest percentage increase in yield compared to the control (2590.21 $\mathrm{kgha}^{-1}$ ) with the application of EM was recorded in 2017. Variant 2 (3107.40 $\mathrm{kgha}^{-1}$ ) increased grain yield by $19.96 \%$ and variant $4\left(3208.05 \mathrm{kgha}^{-1}\right)$ by $23.85 \%$. According to Trnka et al. (2011) in large parts of southern and central 
Europe, changes in agroclimatic conditions are expressed through increased plant stress and shortening of vegetation, which increases the risk of yield loss (Trnka et al., 2014). Based on the obtained results, it can be said that the application of EM in droughts can alleviate the effect of stress and achieve safer production.

\section{Conclusion}

The use of effective microorganisms can increase the total number of microorganisms, the number of azotobacter and actinomycetes. The increases in the total number are at the level of statistical significance $\mathrm{p}$ $<0.01$ in relation to the control and application of NPK fertilizers only. The differences in the number of examined groups of microorganisms in the application of EM and EM + NPK were not at the level of statistical significance. The largest percentage increase in the examined parameters was in 2017, when water deficit was the highest. Rubin variety, on average, had the largest number of examined groups of microorganisms during the research period. The application of EM can affect a statistically significant increase in the number of microorganisms in conditions when agroclimatic conditions are unfavorable for soybean cultivation. The application of EM can increase the grain yield by $13.29 \%$ using only EM, and in combination with NPK the increase was $15.95 \%$.

\section{References}

Cinnadurai, C., Gopalaswamy, G., \& Balachandar, D. (2013). Diversity of cultivable Azotobacter in the semi-arid alfisol receiving long-term organic and inorganic nutrient amendments. Ann Microbiol, 1 63, 1397 $-1404$.

Đukić, V., Miladinov, Z., Balešević-Tubić, S., Miladinović, J., Đorđević, V., Valan, D., Petrović, K. (2018). Critical moments in soybean production. Proceedings 52nd Conference of Agronomists and Farmers of Serbia Zlatibor, 3444 .

Cvijanović, G., Milošević, N., Jarak, M. (2007). The Importance of Diazotrophs as Biofertilisers in the Maize and Soybean Production. Genetics, 39 (3), 395.

Cvijanović, G., Dozet, G. (2018). Possibility of sustainable production of soybean in climate change in the region of Backa Topola and Novi Sad. Thematic Proceedings of International Scientific Conference, Belgrade, 14-15 December, Serbia, 230-247.

Higa, T. (1991). Effective microorganisms: A biotechnology for mankind. In J.F. Parr, S.B. Homick, and C.E. Whitman (eds.), Proceedings 1st International Conference on Kyusei Nature Farming. U.S. Department of Agriculture, Washington, D.C., USA. p. 8-14.

Higa, T. (2001). Effective Microorganisms in the context of Kyusei Nature Farming: a technology for the future. Paper presented at: 6 th International Conference on Kyusei Nature Farming Pretoria, South Africa.

Jahanban, L., and Lotfifar, O. (2012). Study of the effective organism (EM) application effect on efficacy of chemical and organic fertilizers in corn cultivation (Zea maizs. C704). Plant Production Technology 11, 4352.

Javaid, A (2006). Foliar application of effective microorganisms on pea as an alternative fertilizer. Agron Sustain Dev 26, 257-262.
Javaid, A., Bajwa, R., Rabbani, N., Uzma, M. (2000). EM and VAM Technology in Pakistan. IX: Effect of EM application on growth, yield, nodulation and VA mycorrhizal colonization in Vigna radiata (L) Wilczek. Pak J Biol Sci 3, 694-698.

Kim, J.K. Lee, B.K (2000). Mass production of Rhodopseudomonas palustris as diet for aquaculture. Aquacult Eng 23, 281-293.

Martinez-Romero E., Caballero-Mellado J. (1996): Rhiqobium phylogenies and bacterial genetic diversity. Critical Rev. Plant Sci. 15: 113-140.

Ranjith N.K, Sasikala C., Ramana C.V. (2007). Catabolism of 1 phenylalanine and 1-tyrosine by Rbodobacter sphaeroides OU5 occurs through 3, 4-dihydroxyphenylalanine. Res. Mirobiol. 158, 506-511.

Mandic, V., Djordjevic, S., Stanojevic, B., Bijelica, Z., Krnjaja, V., Tomica, Z., Dragicevic, V. (2016). Effect of bacterial seed inoculation on under maize, and maize yield, Joumal of Entronmental Protection and Ecology 17 (3), 1003-1010.

Martinez-Romero, E. and Caballero-Mellado, J. (1996): Rhizolnum phylogenies and bacterial genetic diversity. Critical Rev. Plant Sci. 15, 113 -140 .

Milanović, T., Popović, V., Vučković, S., Rakaščan, N., Popović, S., Petkovic, Z. (2020). Analysis of soybean production and biogas yield to improve eco-marketing and circular economy Economics of Agriculture, S.1., 67(1), 141-156.

Moulin, L., Munive, A., Dreyfus, B., \& Boivin-Masson, C. (2001). Nodulation of legumes by members of the beta-subclass of Proteobacteria. Nature, 411:948-950.

Murugan, R, \& Kumar, S. (2013). Influence of long-term fertilisation and crop rotation on changes in fungal and bacterial residues in a tropical ricefield soil. Biol Fertil Soils, 49, 847-856.

Priyadi, K. Hadi, A., Siagian, T.H., Nisa, C., Azizah, A., Raihani, N., and Inubushi, K (2005). Effect of soil type, applications of chicken manure and effective microorganisms on comyield and microbial properties of acidic wetland soils in Indonesia. Soil Science ero Plant Nutrition 51, 689-691.

Sabeti, Z., Armin, M., Vaezi, K., Mohamad, R. (2017). Investigation of effective microorganisms application method on alleviation of salt stress effects on root morphology of sweet corn, Farming and Vegetables, 54(2):48-55.

Sangakkara, U.R, Higa, T. (1994). Effect of EM on the growth and yield of selected food crops in Sri Lanka. In: Parr JF, Homick SB, Simpson ME (eds), Proceedings of the 2nd International Conference on Kyusei Nature Farming, USDA, Washington, DC, 118-124.

Trolldenier, G. (1996). Plate Count Technique. In: Methods in Soil Biology. Eds. Franz Schinner, Ellen Kandeler, Richard Ohlinger, Rosa Margesin. Springer-Verlag Berlin Heildeberg, 20-26.

Trnka, M., Olesen, J.E., Kersebaum, KC., Skjelvåg, A.O., Eitzinger, J., Seguin, B., Peltonen-Sainio, P., Orlandini, S., Dubrovsky, M., Hlavinka, P., Balek, J., Eckersten, H., Cloppet, E., Calanca, P., Rötter, R., Gobin, A., Vucetic, V., Nejedlik, P., Kumar, S., Lalic, B., Mestre, A., Rossi, F., Alexandrov, V., Kozyra, J., Schaap, B., Zalud, Z., (2011): Agroclimatic conditions in Europe under climate change. Global Change Biology 17: 2298-2318.

Trnka, M., Rötter, R. P., Ruiz-Ramos, M., Kersebaum, K. C., Olesen, J. E., Zalud, Z. \& Semenov, M. A, (2014). Adverse weather conditions for European wheat production will become more frequent with climate change. Nature Climate Change 4(7), 637-643. DOI: $10.1038 /$ nclimate 2242

Kiaohou, S., Diyou, L., Liang, Z., Hu, W., Hui, W. (2001).Use of EMtechnology in agriculture and environmental management in China. Nat Farm Emimon 2, 9-18. 


\section{Uticaj efektivnih mikroorganizama na parametre biogenosti zemljišta u rizosferi različitih genotipova soje i prinosa soje}

\section{Eltreki Abduladin · Gorica Cvijanović · Vojin Đukić · Nenad Đurić · Zlatica Miladinov · Marija Cvijanović · Asija Mussa Abduladin}

Sažetak: Cilj istraživanja bio je da se utvrdi efekat primene efektivnih mikroorganizama (EM) na osnovne mikrobiološke parametre biogenosti zemljišta i visinu prinosa zma soje. Istraživanja su sprovedena u periodu 20162018. Faktor A su godine 2016-2018; faktor B genotip soje Galina, Sava, Rubin i faktor C primena EM: varijanta 1 kontrola, varijanta 2-EM u zemljište $20 \mathrm{l}$ /ha i folijarni tretmana u fazi razvoja biljaka od tri do četiri troliske $\mathrm{i}$ fazi butonizacije, $5 \mathrm{lha}^{-1}$ ); varijanta 3-NPK dubriva (8:15:15), $300 \mathrm{kgha}^{-1}$ i varijanta 4 - varijanta 2 + varijanta 3 . U toku punog cvetanja utvrdeni su osnovni parametri biogenosti zemljišta ukupan broj mikroorganizama (TNB) i brojnost azotobaktera (AZB) i visinu prinosa zma na kraju vegetacije. Ispitivani faktori su imali statistički značajan uticaj na is pitivane parametre. Parametri biogenosti zemljišta kod varijante $4 \mathrm{EM}+\mathrm{NPK}$ statistički značajno $(\mathrm{p}<0,01)$ bili veći od kontrole i varijante 3. Varijanta 2 uticala je naveću brojnost $\mathrm{p}<0,01 \mathrm{u}$ odnosu na kontrolu dok u odnosu na druge varijante značajnost je bila $p<0,05$ (factor B). U rizosferi genotipa Rubin utvrđena je najveća brojnost svih ispitivanih parametara (faktor C). Varijanta 2 sa EM uticala je na povećanje prinosa od 13,29\% u odnosu na kontrolu što je bilo na nivou $(p<0,05)$, a sa primenom EM+NPK varijanta 4 prinos je bio veći za $15,95 \%$ što je bilo na nivou $(p<0,01)$ značajnosti.

Ključne reči: efektivni mikroorganizmi, soja, biogenost zemljišta, prinos

This article is distributed under the terms of the Creative Commons Attribution 4.0 International License (http://creativecommons.org/licenses/bv/4.0) which permits unrestricted use, distribution and reproduction in any medium, provided you give appropriate credit to the original author(s) and the source, provide a link to the Creative Commons license, and indicate if changes were made. 